\title{
PENGENALAN JIWA WIRAUSAHA DAN MANAJEMEN PRODUKSI SISWA MTS MIFTAHUL ULUM MELALUI PELATIHAN PEMBUATAN TELUR ASIN
}

\section{INTRODUCTION TO MTS MIFTAHUL ULUM STUDENT ENTREPRENEURIAL SOUL, PASURUAN REGENCY THROUGH SALT EGG MANUFACTURING TRAINING}

\author{
Udik Yudiono $^{1)}$, Rosita Dwi Ferdiani ${ }^{2)}$, Iva Nurdiana Nur Farida ${ }^{3)}$, Tatik Retno \\ Murniasih $^{4) *}$, Rahaju ${ }^{5)}$ \\ ${ }^{1)}$ Fakultas Ekonomika dan Bisnis, Universitas PGRI Kanjuruhan Malang \\ email: u_yudiono@unikama.ac.id \\ ${ }^{2)}$ Fakultas Sains dan Teknologi, Universitas PGRI Kanjuruhan Malang \\ email: rositadf@unikama.ac.id \\ ${ }^{3)}$ Fakultas Ekonomika dan Bisnis, Universitas PGRI Kanjuruhan Malang \\ email: ivanurdiana@unikama.ac.id \\ ${ }^{4)}$ Fakultas Sains dan Teknologi, Universitas PGRI Kanjuruhan Malang \\ email: tretnom@unikama.ac.id \\ ${ }^{5)}$ Fakultas Ilmu Pendidikan, Universitas PGRI Kanjuruhan Malang \\ email: ayurakoep@unikama.ac.id
}

\begin{abstract}
ABSTRAK
Siswa MTs Miftahul Ulum sebagian besar berasal dari latar belakang petani dan peternak bebek. Siswa kurang mendapat dukungan keluarga tentang pentingnya pendidikan. Hal ini ditunjukkan banyak siswa yang putus sekolah atau bahkan menikah dini. Berdasarkan permasalahan diperlukan solusi yaitu mengenalkan siswa tentang wirausaha dan manajemen melalui pelatihan pembuatan telur asin sebagai bekal kecakapan hidup. Tim pengabdi melakukan pendampingan pada saat pelatihan pembuatan telur asin. Kegiatan pembuatan telur asin didukung oleh latar belakang keluarga siswa sebagai peternak bebek. Pengasinan merupakan salah satu cara untuk mengawetkan telur agar lebih tahan lama. Telur asin diawetkan dengan bubukan abu dapur. Hasil pengabdian menunjukkan siswa antusias dan senang dengan kegiatan pelatihan. Diharapkan pelatihan ini akan menambah uang saku siswa dan menjadi bekal siswa setelah lulus.
\end{abstract}

Kata kunci: Jiwa Wirausaha, Manajemen Produksi, Telur Asin

\section{ABSTRACT}

Most of the students of MTs Miftahul Ulum come from a background of duck farmers and breeders. Students lack family support regarding the importance of education. This is shown by many students who drop out of school or even marry early. Based on the problem, a solution is needed, namely introducing students to entrepreneurship and management through training in making salted eggs as a provision for life skills. The service team provides assistance during the salted egg making training. The activity of making salted eggs is supported by the student's family background as duck breeders. Salting is one way to preserve eggs to make them more durable. Preserved salted eggs with kitchen ashes. The results of the dedication showed that the students were enthusiastic and happy with the training activities. It is hoped that this training will increase students' pocket money and become provisions for students after graduation.

Keywords: Entrepreneurial Spirit, Production Management, Salted Eggs

\section{PENDAHULUAN}

Mts Miftahul Ulum Ngembal berlokasi

di Kabupaten Pasuruan kurang lebih 45 km dari kota Malang. Mts Miftahul Ulum dapat ditempuh 1 jam lebih 30 menit dari Universitas PGRI Kanjuruhan Malang. Sekolah ini didirikan pada tahun 2000 dan berlokasi di Jalan Krajan Barat, desa 
Ngembal, Kecamatan Tutur, Kabupaten Pasuruan.

Pada awal berdiri, sekolah ini belum mempunyai gedung sendiri. Proses pembelajaran meminjam gedung SDN Ngembal I dengan dibantu 10 orang tenaga guru. Sekolah Mts Miftahul Ulum mulai membangun gedung sekolah pada tahun 2003.

MTs Miftahul Ulum merupakan sekolah menengah satu-satunya di desa Ngembal. Hal inilah yang menyebabkan sekolah ini tidak pernah kekurangan siswa. Jumlah total siswa yang terdaftar di MTs Miftahul Ulum Ngembal tahun pelajaran 2019-2020 ada 255 siswa.

Berdasarkan hasil wawancara dengan kepala sekolah dan beberapa guru di Mts Miftahul Ulum yang dilakukan pada bulan Juni 2020 diperoleh informasi bahwa latar belakang keluarga siswa adalah peternak bebek dan petani. Hal ini menyebabkan siswa kurang mendapat dukungan dari keluarga tentang pentingnya pendidikan. Bahkan sering terjadi, siswa putus sekolah dikarenakan harus bekerja atau menikah di usia dini.

Banyak keluarga yang beternak bebek menyebabkan produksi telur bebek sangat banyak. Telur bebek yang sangat banyak membutuhkan pengawetan agar tahan lama sehingga tidak lekas busuk dan memberikan manfaat lebih baik [1]. Umumnya peternak langsung menjual hasil telur tersebut ke pedagang dan jarang terpikirkan untuk mengolah hasil telur tersebut menjadi olahan lain.

Pengolahan lebih lanjut telur bebek menjadi telur asin dapat mengoptimalkan potensi telur sebagai produk pangan yang praktis, tahan lebih lama, bergizi tinggi dan mempunyai nilai jual yang tinggi [2], [3] Mempertimbangkan latar belakang keluarga siswa, maka perlu untuk mengadakan kegiatan pengabdian yang melibatkan siswa melalui pelatihan dan pendampingan. Tujuan pengabdian ini akan memberi manfaat pada siswa yaitu melatih jiwa wirausaha dan manajemen produksi melalui pembuatan telur asin. Selain itu hasil penjualan telur asin juga dapat menambah uang saku dan sebagai bekal kecakapan hidup kelak di masyarakat.

\section{METODE PELAKSANAAN KEGIATAN}

Pengabdi ingin menawarkan solusi terhadap permasalahan yang terjadi. Salah satunya adalah menambah pengetahuan siswa tentang kewirausahaan dan manajemen produksi sehingga siswa putus sekolah mempunyai bekal untuk hidup [4]. Selain itu juga pelatihan dan pendampingan pembuatan telur asin kepada siswa. Secara umum alur kegiatan pengabdian dapat digambarkan seperti Gambar 1. berikut ini. 


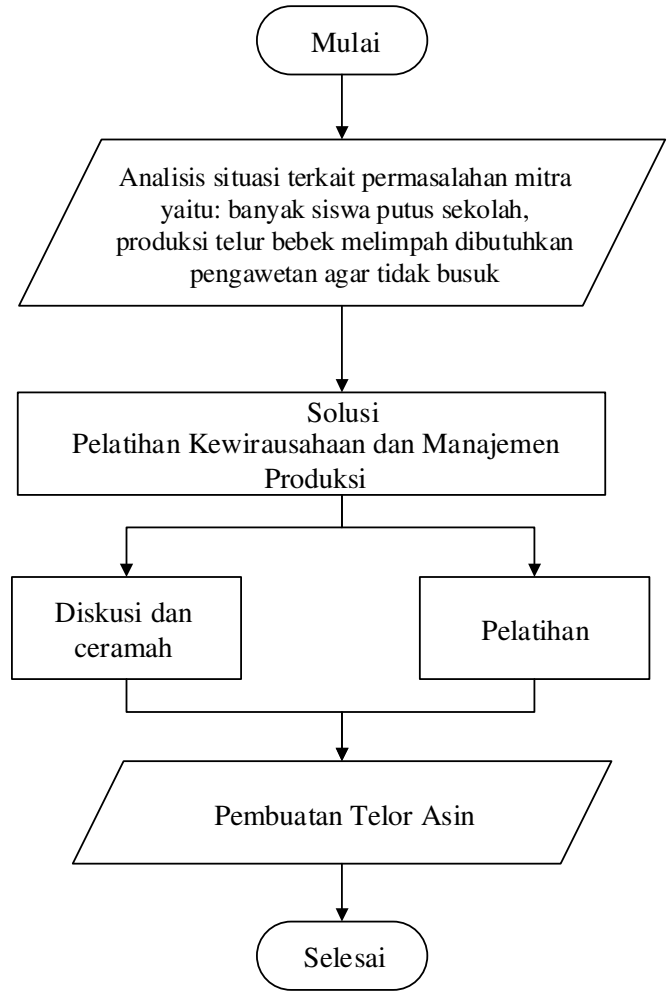

Gambar 1. Alur kegiatan pengabdian

Demi keberhasilan dan keberlanjutan program diperlukan partisipasi aktif dari sekolah mitra dalam pelaksanaan kegiatan pengabdian. Guna mendorong partisipasi aktif dari sekolah dalam pelaksanaan pengabdian dilakukan beberapa hal sebagai berikut.

a. Pendampingan mitra.

Pendampingan pada siswa dalam bentuk diskusi dan ceramah [5]. Pendampingan ini bermanfaat untuk menambah pengetahuan terkait pembuatan telur asin.

b. Pelatihan kewirausahaan dan manajemen produksi melalui pembuatan telur asin.

Pelatihan dilakukan oleh tim pengabdi kepada siswa secara langsung sehingga memudahkan dalam alih ilmu melalui praktek.

\section{HASIL DAN PEMBAHASAN}

Berdasarkan analisis situasi didapatkan banyak siswa putus sekolah. Selain itu produksi telur bebek juga melimpah. Pengabdi memberikan pelatihan kewirausahaan dan manajemen produksi telur asin. Pengabdian dilakukan selama 4 kali pertemuan (lihat Tabel 1.).

Tabel 1. Deskripsi kegiatan pengabdian tiap pertemuan

\begin{tabular}{cl}
\hline Pertemuan & \multicolumn{1}{c}{ Kegiatan } \\
\hline 1 & $\begin{array}{l}\text { Pelatihan kewirausahaan dan } \\
\text { manajemen produksi } \\
\text { pembuatan telur asin dalam } \\
\text { bentuk diskusi, ceramah dan } \\
\text { pendampingan }\end{array}$ \\
2 & $\begin{array}{l}\text { Pelatihan dan pendampingan } \\
\text { pembuatan telur asin }\end{array}$ \\
3 & $\begin{array}{l}\text { Pelatihan dan pendampingan } \\
\text { pengemasan telur yang masih } \\
\text { mentah dan dalam proses } \\
\text { pengasinan } \\
\text { Pelatihan dan pendampingan } \\
\text { pengukusan telur asin serta } \\
\text { memilih telur yang bagus } \\
\text { untuk dijual }\end{array}$ \\
\hline
\end{tabular}

Kegiatan pelatihan dan pendampingan diawali dengan pendampingan dalam bentuk diskusi dan ceramah (lihat Gambar 1.).

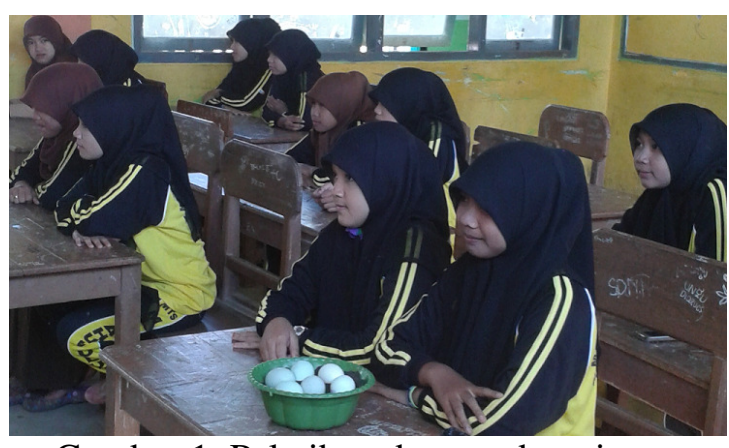

Gambar 1. Pelatihan dan pendampingan berupa diskusi dan ceramah

Selanjutnya pendampingan dalam praktik pembuatan telur asin. Berikut dipaparkan urutan praktik dan pendampingan pembuatan telur asin yaitu. 
1. Telur bebek dicuci bersih dengan air.

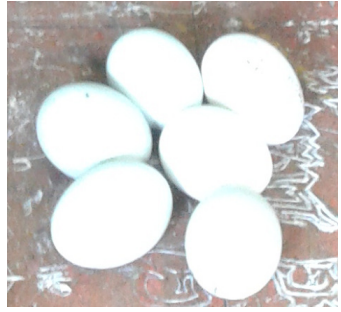

Gambar 2. Telur bebek yang sudah dibersihkan

Telur dipilih yang berkualitas baik dan tidak busuk agar didapatkan kualitas telur asin yang bagus [6].

2. Balur telur dengan abu gosok yang dicampur air dan garam

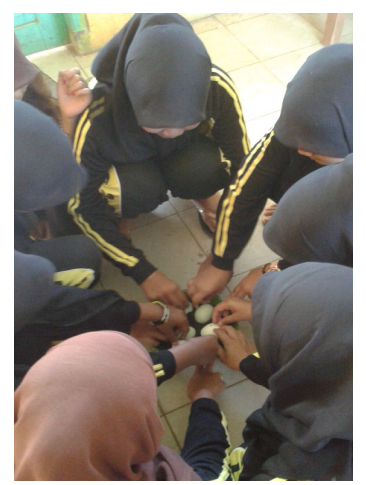

Gambar 3. Siswa membalur telur dengan abu gosok

Pengasinan dilakukan dengan cara mencampurkan garam dan abu gosok dengan perbandingan tiga dibanding dua. Abu gosok dan garam selanjutnya dicampurkan dengan air [7].

3. Diamkan telur yang sudah dibalur dengan abu gosok selama 14 hari.

Cara pengeraman telur selama 14 hari didapat dari pengalaman [7].

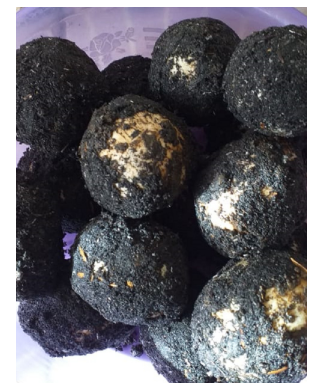

Gambar 4. Telur dibiarkan selama 14 hari
Kegiatan pelatihan kewirausahaan dan manajemen produksi diberikan pengabdi dengan memberikan ceramah secara teori dan praktik. Telur asin tidak hanya dijual dalam kondisi matang tetapi juga bisa dijual dalam kondisi mentah. Agar menarik pembeli maka telur yang sudah dalam proses pengasinan diberi bungkus plastik (Gambar 5.).

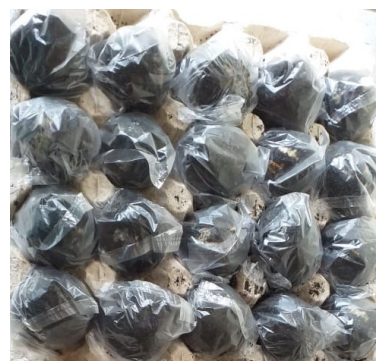

Gambar 5. Pengemasan telur asin mentah

Selain itu pengabdi juga memberikan pendampingan sampai telur asin siap untuk dimasak. Setelah hari ke 14 telur asin dibersihkan dan dapat dimasak (Gambar 6.).

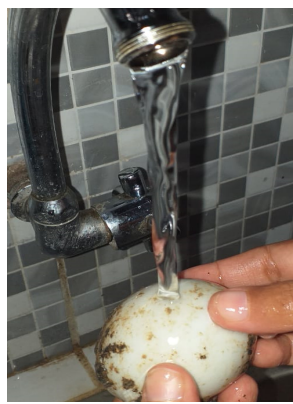

Gambar 6. Telur asin dicuci bersih

Telur asin yang bagus setelah dicuci akan berwarna jernih apabila diteropong dengan lampu [8] (Gambar 7.).

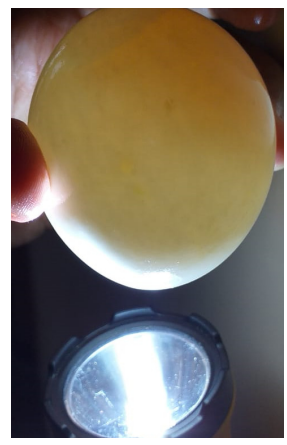

Gambar 7. Meneropong telur dengan lampu

Selama kegiatan pengabdian siswa 
antusias dan sangat senang. Hal ini ditunjukkan dengan siswa selalu hadir selama empat kali kegiatan pelatihan dan pendampingan berlangsung.

\section{KESIMPULAN}

Kegiatan pengabdian membuat siswa senang. Selain itu juga siswa mendapatkan bekal ilmu kewirausahaan dan manajemen pembuatan telur asin. Pengetahuan yang didapat selama pelatihan dan pendampingan dapat digunakan untuk mulai menjalankan usaha produksi telur asin sehingga menjadi alternatif pemecahan masalah bagi siswa yang putus sekolah.

\section{SARAN}

Kegiatan pengabdian diharapkan bisa berkelanjutan. Pelatihan pengemasan, pemberian merk, pemasaran, dan varian rasa telur asin direkomendasikan untuk pengabdian lanjutan. Hal ini bertujuan agar siswa mempunyai bekal hidup di masyarakat.

\section{UCAPAN TERIMAKASIH}

Terimakasih kepada semua pihak yang terkait dengan kegiatan pengabdian antara lain: Universitas PGRI Kanjuruhan Malang yang telah mendanai kegiatan pengabdian dan juga seluruh keluarga besar MTs Miftahul Ulum Ngembal yang telah menerima kami guna melakukan salah satu kegiatan tri dharma.

\section{REFERENSI}

[1] Nuruzzakiah, R. H. dan Syafrianti D. 2016. Pengaruh konsentrasi garam terhadap kadar protein dan kualitas organoleptik telur bebek. Jurnal Ilmiah Mahasiswa Pendidikan Biologi. 1(1): 19.

[2] Surya E., Apriana E., dan Fanisah F. 2017. Pengaruh penambahan beberapa jenis asam terhadap proses pengolahan telur asin untuk menghilangkan bau amis. Jurnal Edubio Tropika. 5(2): 86-92.

[3] Engelen, A., Umela, S., dan Hasan A. 2017. Pengaruh lama pengasinan pada pembuatan telur asin dengan cara basah. Jurnal Agroindustri Halal. 3(2): 133141.

[4] Tamam, B., Agustini, N. P., Puryana, I., dan Suratiah. 2020. Pengembangan jiwa kewirausahaan mahasiswa dalam memproduksi tempe dan olahannya melalui campus tempeh. Logista: Jurnal Ilmiah Pengabdian Kepada Masyarakat. 4(2): 514-518.

[5] Ferdiani, R. D., Murniasih, T. R., Wilujeng, S., dan Suwanti, V. 2018. Penambahan alat produksi guna meningkatkan produktivitas pengrajin keset. Jurnal Pengabdian dan Pemberdayaan Masyarakat. 2(1): 23-28

[6] Salim, E., Syam, H., dan Wijaya M. 2017. Pengaruh variasi waktu pemeraman telur asin dengan penambahan abu sabut kelapa terhadap kandungan kadar klorida, kadar protein dan tingkat kesukaan konsumen. Jurnal Pendidikan Teknologi Pertanian. 3(1): 107-116.

[7] Lesmayati, S., dan Rohaeni, E. S. 2014. Pengaruh lama pemeraman telur asin terhadap tingkat kesukaan konsumen. Prosiding Seminar Nasional. "Inovasi Teknologi Pertanian Spesifik Lokasi”. 1(4): 595-601.

[8] Wibowo, D., Widanti, Y., dan Mustofa A. 2017. Penambahan ekstrak jahe (Zingiber officinale var amarum) dan ekstrak kunyit putih (Curcuma zedoaria) pada pembuatan telur asin dengan variasi lama pemeraman. Jurnal Teknologi Pertanian. 8(2): 1-7. 